\title{
Article \\ Superior Proton Exchange Membrane Fuel Cell (PEMFC) Performance Using Short-Side-Chain Perfluorosulfonic Acid (PFSA) Membrane and Ionomer
}

\author{
Nana Zhao (), Zhiqing Shi *(1) and Francois Girard \\ Energy, Mining \& Environment Research Centre, National Research Council Canada, 4250 Wesbrook Mall, \\ Vancouver, BC V6T 1W5, Canada; Nana.Zhao@nrc-cnrc.gc.ca (N.Z.); Francois.Girard@nrc-cnrc.gc.ca (F.G.) \\ * Correspondence: Zhiqing.Shi@nrc-cnrc.gc.ca
}

check for

updates

Citation: Zhao, N.; Shi, Z.; Girard, F. Superior Proton Exchange Membrane Fuel Cell (PEMFC) Performance Using Short-Side-Chain Perfluorosulfonic Acid (PFSA)

Membrane and Ionomer. Materials 2022, 15, 78. https://doi.org/ $10.3390 / \mathrm{ma} 15010078$

Academic Editor:

Aleksey Yaremchenko

Received: 17 November 2021

Accepted: 17 December 2021

Published: 23 December 2021

Publisher's Note: MDPI stays neutral with regard to jurisdictional claims in published maps and institutional affiliations.

Copyright: (c) 2021 by the authors Licensee MDPI, Basel, Switzerland. This article is an open access article distributed under the terms and conditions of the Creative Commons Attribution (CC BY) license (https:/ / creativecommons.org/licenses/by/ $4.0 /)$.

\begin{abstract}
Optimization of the ionomer materials in catalyst layers (CLs) which sometimes is overlooked has been equally crucial as selection of the membranes in membrane electrode assembly (MEA) for achieving a superior performance in proton exchange membrane fuel cells (PEMFCs). Four combinations of the MEAs composed of short-side-chain (SSC) and long-side-chain (LSC) perfluorosulfonic acid (PFSA) polymers as membrane and ionomer materials have been prepared and tested under various temperatures and humidity conditions, aiming to investigate the effects of different side chain polymer in membranes and CLs on fuel cell performance. It is discovered that SSC PFSA polymer used as membrane and ionomer in CL yields better fuel cell performance than LSC PFSA polymer, especially at high temperature and low RH conditions. The MEA with the SSC PFSA employed both as a membrane and as an ionomer in cathode CL demonstrates the best cell performance amongst the investigated MEAs. Furthermore, various electrochemical diagnoses have been applied to fundamentally understand the contributions of the different resistances to the overall cell performance. It is illustrated that the charge transfer resistance $\left(R_{c t}\right)$ made the greatest contribution to the overall cell resistance and then membrane resistance $\left(R_{m}\right)$, implying that the use of the advanced ionomer in CL could lead to more noticeable improvement in cell performance than only the substitution as the membrane.
\end{abstract}

Keywords: ionomer; long side chain; membrane; perfluorosulfonic acid; PEM fuel cell; short side chain

\section{Introduction}

Proton exchange membrane fuel cells (PEMFCs) have been widely considered to be a critical conversion technology in a hydrogen-based energy infrastructure due to their high theoretical energy efficiency and zero-emission [1,2]. The proton exchange membrane (PEM) functioning as a proton conductor as well as a separator for electrodes and reactant gas was recognized as one of the most expensive stack component and a key component to determine the cell performance [3]. On the other hand, the microstructure of electrode has a profound effect on the utilization of platinum and its durability [4]. Particularly, the ionomer in the catalyst layer can affect the degree of ionic contact, the connectivity of the ionic conduction path, the proton conductivity, the gas diffusivity, etc. Therefore, the proton exchange polymers employed in PEMFC as membrane and as binder/proton conductor in the catalyst layer (CLs) are equally crucial to the entire cost and performance of a PEMFC.

Perfluorosulfonic acid (PFSA) polymers have been widely used as PEMs and as ionomers in CLs. Currently, the premiere commercial PFSA used in PEMFCs is Nafion ${ }^{\circledR}$, a long-side-chain (LSC) ionomer, produced previously by DuPont and now Chemours, which is a brand name for a sulfonated tetrafluoroethylene based fluoropolymer discovered in the late 1960s by Walther Grot of DuPont [5]. The Nafion polymer structure consists of a hydrophobic polytetrafluoroethylene backbone and perfluorovinyl ether side chains terminated by a triflic acid group $\left(-\mathrm{CF}_{2} \mathrm{SO}_{3} \mathrm{H}\right)$ [6]. Although Nafion ${ }^{\mathrm{TM}}$ possesses many desirable 
attributes, it has the recognized limitation of insufficient proton conductivity under low humidity and a limited range of operating temperature $\left(<90{ }^{\circ} \mathrm{C}\right)$. Furthermore, the proton conductivity depends on the ratio and phase separation of hydrophobic backbone and hydrophilic side chains [7]. The short-side-chain (SSC) PFSA polymer with a similar structure as Nafion, but bearing a shorter $-\mathrm{OCF}_{2} \mathrm{CF}_{2} \mathrm{SO}_{3} \mathrm{H}$ pendant chain, has been considered as a promising candidate for PEMFC applications due to the higher crystallinity, the higher thermal transition temperature, and the higher ion exchange capacity (IEC) compared to LSC ionomer [8]. SSC polymer was originally synthesized by Dow Chemical [9] and its superior fuel cell performance was firstly demonstrated by Ballard Power Systems in the mid-1980s [10]. In 2010, Solvay-Solexis developed a simpler approach to synthesize SSC PFSA polymers under the trademark "Aquivion ${ }^{\circledR}$ ", reporting higher IEC value, higher water uptake, similar mechanical properties, higher glass transition temperature, and comparable price with respect to Nafion [11].

A number of research reports have demonstrated the distinct advantage of SSC PFSA ionomers in fuel cells [12-22]. It was reported that the SSC PFSA membranes exhibited higher fuel cell performance than Nafion under low humidity as well as higher power density, better fuel cell reliability, and settling time upon start-up in self-humidifying PEMFCs under the optimal operating conditions $[14,18]$. With the incorporation of the SSC PFSA ionomer only in CLs, an increase in cell voltage was observed compared to the cell with Nafion as ionomer [12,13,19-21]. Arico's group [15] compared the fuel cell performance between Aquivion ${ }^{\circledR}$ E79-03S SSC $\left(130{ }^{\circ} \mathrm{C}\right)$ and LSC Nafion ${ }^{\circledR}$ PFSA membranes as baselines at a high temperature and found the Aquivion-based membrane electrode assembly (MEA) showed better performance due to their intrinsic properties of SSC such as the larger crystallinity, higher glass transition temperature, and higher IEC. Shahgaldi et al. [7] experimentally investigated the impact of different catalyst-SSC ionomer ratios and catalyst loadings on PEMFC performance and durability with an accelerated stress test. Ren et al. [21] reported that the electrode composed of SSC ionomer has better proton conductivity but higher mass transport resistance than Nafion, which is still superior in the ultimate performance. Although considerable efforts have been devoted to investigating SSC PFSA polymer either as a membrane or as a binder in CLs, reporting the comparative studies on the combination of SSC and LSC PFSA as a membrane and as an ionomer in CLs to achieve the best PEMFC performance are not-so-well documented. More recently, Talukdar's group [17] compared performance and durability between LSC and SSC PFSA polymers as a membrane and as an ionomer-additive in the electrodes, whereas they were focused on the short-term and long-term durability test. In their short-term test, they found SSC has better performance but higher degradation rate than LSC. In the long-term test, the cell durability was improved by increasing the membrane thickness with double SSC membranes. Furthermore, it is commonly agreed that the SSC polymer as either a membrane or ionomer in CL can usually deliver higher performance than the LSC polymer does. The question of whether the SSC membrane or the SSC ionomer impacts more on fuel cell performance than the LSC polymer has not been addressed.

In our present work, a comprehensive study is carried out to compare the fuel cell performance between the MEAs with a combination of both SSC and LSC polymers in the membranes as well as the ionomers in CL under various operation conditions in order to understand the correlations between the MEA composition and fuel cell performance. The complicated influence of polymers with different side chain lengths on PEMFC performance was addressed by means of in-situ EIS and the analysis of the relative contribution of individual resistance, including membrane resistance, charge transfer resistance and mass transfer resistance, to the overall resistance generated during fuel cell testing. The understanding of the role of each component in MEAs from this work is essential to optimize and improve fuel cell performance and could provide deep insight regarding polymer material selection and MEA design for PEMFC applications. 


\section{Materials and Methods}

\subsection{Materials}

Nafion ${ }^{\circledR}$ NR211 membrane (NRE211, $25 \mu$ m LSC PFSA, DuPont, DE, USA) and Aquivion ${ }^{\circledR}$ E79-03S membrane (AQ(E79), $30 \mu \mathrm{m}$, SSC PFSA, Solvay-Solexis) were used asreceived. The Nafion ${ }^{\circledR}$ LSC ionomer dispersion (D-520, $5 \mathrm{wt} \%$ solution, EW1100, DuPont) and the Aquivion ${ }^{\circledR}$ SSC ionomer dispersion (D83-15C, 15 wt\% solution, EW 830, Solvay Solexis) were used as the ionomers in CLs.

\subsection{Fabrication of Membrane-Electrode-Assemblies (MEAs)}

Catalyst inks were prepared by dispersing $46 \mathrm{wt} \% \mathrm{Pt} / \mathrm{C}$ (Tanaka Kikinzoku Kogyo, Tokyo, Japan) with ionomer into the mix solvent of 1:1 methanol/water. The solid content of the inks was $\sim 1 \mathrm{wt} \%$. The Nafion ${ }^{\circledR}$ D-520 ionomer content in the cathode CL was $30 \mathrm{wt} \%$ while the Aquivion ${ }^{\circledR}$ D83-15C ionomer content in the CL was $20 \mathrm{wt} \%$. The anode CL for all MEAs contained $30 \mathrm{wt} \%$ Nafion ${ }^{\circledR}$ D-520 ionomer. An automated spray coater (EFD Ultra TT series) was employed to fabricate the anode CL $\left(0.2 \mathrm{mg} \mathrm{Pt} \mathrm{cm}^{-2}\right)$ and the cathode CL $\left(0.4 \mathrm{mg} \mathrm{Pt} \mathrm{cm}^{-2}\right)$. The active area of CCMs is $25 \mathrm{~cm}^{2}$. Detailed fabrication procedures have been reported [14,23]. The investigated MEAs are listed in Table 1.

Table 1. List of the investigated MEAs.

\begin{tabular}{cccc}
\hline \multirow{2}{*}{ Name of MEAs } & \multirow{2}{*}{ Membrane } & \multicolumn{2}{c}{ Cathode CL } \\
\cline { 3 - 4 } & & Ionomer & Content \\
\hline NRE211/NF30 & Nafion $^{\circledR}$ NR211 & Nafion ${ }^{\circledR}$ D-520 & $30 \%$ \\
\hline NRE211/AQ20 & Nafion $^{\circledR}$ NR211 & Aquivion $^{\circledR}$ D83-15C & $20 \%$ \\
\hline AQ(E79)/NF30 & Aquivion $^{\circledR}$ E79-03S & Nafion $^{\circledR}$ D-520 & $30 \%$ \\
\hline AQ(E79)/AQ20 & Aquivion $^{\circledR}$ E79-03S & Aquivion $^{\circledR}$ D83-15C & $20 \%$ \\
\hline
\end{tabular}

* $30 \mathrm{wt} \%$ Nafion ${ }^{\circledR} \mathrm{D}-520$ ionomer in all anode CLs.

\subsection{MEAs and Single Cells}

CCMs were inserted between two 24BC-type gas diffusion layers (SGL Group) to fabricate MEAs (see Figure S1) and assembled into single cells (Scribner Associates Inc. Southern Pines, NC, US). The uniformity of the cell compression was validated by the pressuresensitive films (Pressurex-Super Low, Sensor Products Inc. Madison, WI, USA). Single cells were evaluated in a fuel cell test station $(100 \mathrm{~W}$, Scribner $850 \mathrm{C}$, Scribner Associates Inc. Southern Pines, NC, USA).

\subsection{Fuel Cell Testing Protocol}

The MEAs were conditioned at $1.0 \mathrm{~A} \mathrm{~cm}^{-2}, 100 \%$ relative humidity $(\mathrm{RH}), 80{ }^{\circ} \mathrm{C}$ for at least $10 \mathrm{~h}$. Air and $\mathrm{H}_{2}$ (purity 99.999\%) were used as the cathode and anode reactants with 5 standard liter per minute (SLPM) and 2 SLPM of flow rate, respectively. The humidifiers are dual sparger-type with $360 \mathrm{~W}$ heaters per bottle. The membrane resistance $\left(\mathrm{R}_{\mathrm{Membr}}\right.$.) was measured by current interrupt method.

Electrochemical surface area (ECSA) was measured by cyclic voltammetry (CV) using a potentiostat (1287A, Solartron Analytical). The cathode were purged with humidified $\mathrm{N}_{2}$ (0.5 SLPM) for $30 \mathrm{~min}$. The $\mathrm{N}_{2}$ flow was then set to zero and $\mathrm{H}_{2}$ flow rate keeps 0.5 SLPM, and voltammograms were then recorded with a scan rate of $50 \mathrm{mV} \cdot \mathrm{s}^{-1}$ between $0.04 \mathrm{~V}$ and $0.90 \mathrm{~V}$ versus the anode. The final cycle of a set of 10 cycles was used for data analysis. The ECSAs of the MEAs were calculated from the integrated charge corresponding to the $\mathrm{Pt}-\mathrm{H}$ desorption and adsorption peaks. The double-layer capacitances of the CLs were also obtained from CV.

The $\mathrm{H}_{2}$ cross-over current density was measured by linear sweep voltammetry (LSV) with a scan rate of $2 \mathrm{mV} \mathrm{s}^{-1}$ between $0.1 \mathrm{~V}$ and $0.6 \mathrm{~V}$ versus the anode under 0.5/0.5 SLPM $\mathrm{H}_{2} / \mathrm{N}_{2}$ (anode/cathode) gas flow rates. 
The ionic resistance in the CLs was evaluated by ex-situ EIS using a Solartron 1287A potentiostat and a 1260 frequency response analyzer. The testing was conducted with the flow rates of 0.5 SLPM/0.5 SLPM for $\mathrm{H}_{2}$ and $\mathrm{N}_{2}$, respectively, at $100 \% \mathrm{RH}$, and $80{ }^{\circ} \mathrm{C}$. The amplitude of the sinusoidal current signal for the AC impedance was set at $10 \mathrm{mV}$ over a frequency range of $20 \mathrm{kHz}$ to $0.1 \mathrm{~Hz}$.

The ORR kinetics of these CLs were determined by acquiring $\mathrm{H}_{2} / \mathrm{O}_{2}$ polarization curves at gas flow rates of 2 SLPM H$~_{2}$ and 5 SLPM O $\mathrm{S}_{2}$ without back pressure. The current load was gradually decreased in controlled steps from $1 \mathrm{~A} \mathrm{~cm}^{-2}$ to $0.008 \mathrm{~A} \mathrm{~cm}^{-2}$. Each point was held for $10 \mathrm{~min}$. The cell voltage at each current was obtained by averaging the data recorded in the last $2 \mathrm{~min}$. The $i R$-corrected cell potentials were plotted against the $\log$ of compensated current density, and the Tafel slope was extracted.

The cell performances of these MEAs were evaluated at $80^{\circ} \mathrm{C}$ and $95^{\circ} \mathrm{C}$ under different RHs (100\%, 70\%, 50\%, and 30\%) for both anode and cathode without back pressure. The $\mathrm{H}_{2}$ /air polarization curves were obtained galvanostatically. Each point was held for $10 \mathrm{~min}$. The cell potential was obtained by averaging the data from the last $2 \mathrm{~min}$.

The $i R$ correction to voltages were calculated by the Equation (1):

$$
E_{i R \text { correction }}=E_{\text {Measured }}+i R_{\text {Membr. }}
$$

where $E_{i R \text { correction }}$ and $E_{\text {Measured }}$ represent $i R$ correction cell voltage and the cell voltage measured in $\mathrm{H}_{2}$ /air polarization curve, respectively. $i$ is the current and $R_{M e m b r}$. is the membrane resistance collected by the current interrupt method.

In-situ EIS was conducted during polarization curve collections (under constant direct current (DC)) by imposing an amplitude alternating current (AC) signal to the fuel cell via a load bank. The perturbation amplitude for the AC impedance was $5 \%$ of the direct current over a frequency range of $10 \mathrm{kHz}$ to $0.1 \mathrm{~Hz}$. The voltage responses were recorded and decoupled by a built-in frequency response analyzer (FRA, Scribner 880).

\section{Results}

\subsection{Electrochemical Surface Area (ECSA)}

The ECSA of $\mathrm{Pt}$ catalyst in the cathode was evaluated by cyclic voltammetry (CV). Figure 1 shows the CVs of different CLs in MEAs at $80{ }^{\circ} \mathrm{C}$ and $100 \%$ RH. The Nafion ${ }^{\circledR}$-based CLs (NRE211/NF30 and AQ(E79)/NF30) exhibit characteristic features of hydrogen adsorption/desorption and oxide formation/reduction that are similar to the Aquivion ${ }^{\circledR}$-based CLs (NRE211/AQ20 and AQ(E79)/AQ20). ECSA data and double layer capacitances $\left(\mathrm{C}_{\mathrm{dl}}\right)$ for the selected four MEAs are also presented in Table 2. The ECSA from desorption peaks (voltage range from $0.11 \mathrm{~V}$ to $0.40 \mathrm{~V}$ ) and $\mathrm{C}_{\mathrm{dl}}$ values were close for all the samples, between 37.5 and $39.6 \mathrm{~m}^{2} \mathrm{~g}^{-1}$ and 19.0 and $20.3 \mathrm{mF} \mathrm{cm}{ }^{-2}$, respectively, indicating that the availabilities and coverage of $\mathrm{Pt}$ nanoparticles by the LSC ionomer and SSC ionomer are similar.

\subsection{Hydrogen Crossover Current}

Hydrogen crossover currents $\left(\mathrm{iH}_{\mathrm{X}}\right)$ through the MEAs were detected by LSV. The oxidation current densities at $80{ }^{\circ} \mathrm{C}$ and $100 \% \mathrm{RH}$ were found to be less than $1.6 \mathrm{~mA} \mathrm{~cm}^{-2}$ for all the MEAs (see Table 2). These low crossover currents attributed to less than $2 \%$ of the current density of a fuel cell operating, e.g., $0.8-0.3 \mathrm{~V}, 0.1-1.8 \mathrm{~A} \mathrm{~cm}^{-2}$, (see polarization curves below), suggesting that the efficiency loss is negligible due to the $\mathrm{H}_{2}$ crossover from anode to cathode in these MEAs. In addition, the crossover currents are nearly the same for the two SSC membrane-based MEAs $\left(\sim 1.2 \mathrm{~mA} \mathrm{~cm}^{-2}\right)$, while they are slightly lower than that of LSC Nafion based MEAs $\left(\sim 1.6 \mathrm{~mA} \mathrm{~cm}^{-2}\right)$, indicating that the differences between these MEAs in $\mathrm{H}_{2}$ crossover are dictated only by the membrane, and thus SSC AQ(E79) has a lower hydrogen crossover than LSC NRE-211. The lower $\mathrm{H}_{2}$ crossover for SSC AQ(E79) could possibly be elucidated by the free volume theory from Sodaye and Mohamed et al. [24,25]. SSC AQ(E79) has higher crystallinity, greater IEC (1.26 vs. $0.9 \mathrm{meq} \mathrm{kg}^{-1}$ ) and better water uptake than Nafion [11,26], leading to the 
greater volume of the hydrophilic cluster in the hydrated AQ(E79) than that in NRE211, as a consequence, the less free volume for the hydrogen crossover [27].

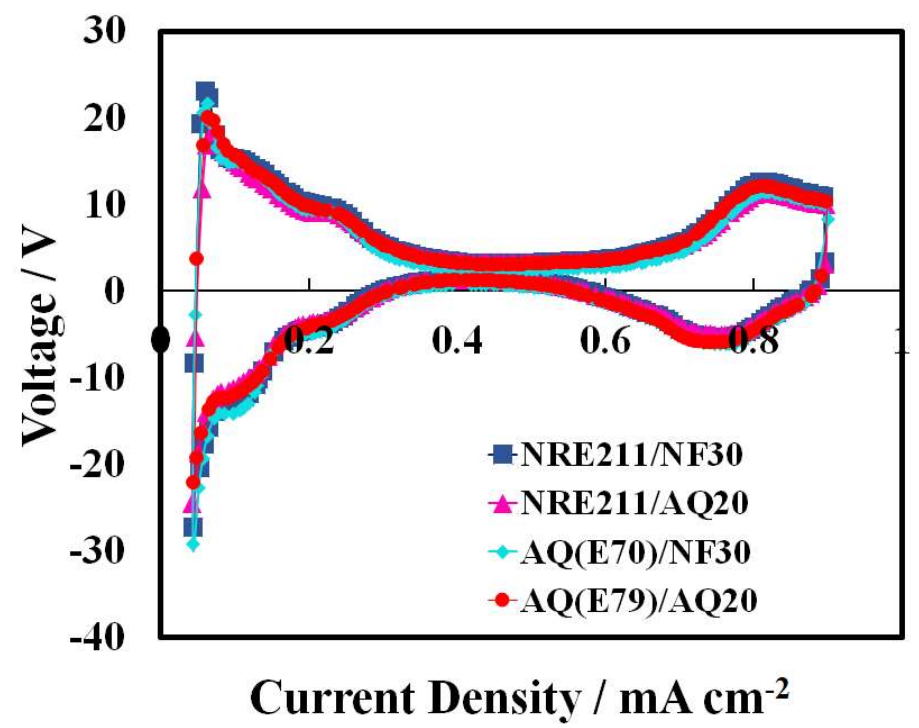

Figure 1. Typical cyclic voltammograms of cathode CLs in MEAs at $80{ }^{\circ} \mathrm{C}$ and $100 \% \mathrm{RH}$.

Table 2. Electrochemical performance of the four investigated MEAs measured at $80{ }^{\circ} \mathrm{C}$ and $100 \%$ of RH.

\begin{tabular}{|c|c|c|c|c|c|}
\hline MEAs & $\begin{array}{l}\text { Electrochemical } \\
\text { Surface Area ECSA } \\
\text { (Desorption) } \\
\left(\mathrm{m}^{2} \mathrm{~g}^{-1}\right)\end{array}$ & $\begin{array}{c}\text { Double Layer } \\
\text { Capacitances } \\
\mathrm{C}_{\mathrm{dl}} \\
\left(\mathrm{mF} \mathrm{cm}^{-2}\right)\end{array}$ & $\begin{array}{c}\mathrm{H}_{2} \\
\text { Crossover } \\
\text { Current } \\
\mathrm{iH}_{\mathbf{X}} \\
\left(\mathrm{mA} \mathrm{cm}^{-2}\right)\end{array}$ & $\begin{array}{c}\text { Proton } \\
\text { Resistance } \\
R_{\mathrm{p}} \\
(\mathrm{MEA}) \\
\left(\mathrm{m} \Omega \mathrm{cm}^{2}\right)\end{array}$ & $\begin{array}{l}\text { Tafel Slope } \\
\left.(\mathrm{mV} \mathrm{dec})^{-1}\right)\end{array}$ \\
\hline NRE211/NF30 & 38.0 & 20.3 & 1.60 & 99 & 67 \\
\hline NRE211/AQ20 & 37.5 & 19.6 & 1.58 & 163 & 65 \\
\hline AQ (E79)/NF30 & 39.6 & 19.0 & 1.24 & 109 & 70 \\
\hline AQ (E79)/AQ20 & 38.0 & 20.1 & 1.20 & 174 & 67 \\
\hline
\end{tabular}

\subsection{Protonic Resistance in the CL}

The proton conductivities of the CLs were measured by EIS at $80{ }^{\circ} \mathrm{C}$ and $100 \% \mathrm{RH}$. Impedance spectra of four MEA samples under this test condition are presented as Nyquist plots in Figure 2, respectively. In order to make clear, the spectra are shifted to the origin by removing the high-frequency resistance from the real axis. The protonic and electronic resistances inside the CLs were calculated by fitting the experimental data by a transmission line equivalent circuit [23]. The proton resistance $\left(R_{p}\right)$ values are also summarized in Table 2 .

As a result, there are no obvious differences in protonic resistance (or conductivity) between either Nafion ${ }^{\circledR}$-electrodes (NF30) or Aquivion ${ }^{\circledR}$-electrodes (AQ20) due to the similar coverage of carbon surface with fully hydrated ionomers at $100 \% \mathrm{RH}$. However, in comparison between NF30 based MEAs and AQ20 based MEAs, AQ20 exhibited a greater proton transport resistance (lower proton conductivity) of the CLs due to their relatively lower ionomer content, while at the same ionomer loading (30\%), AQ30 was reported to have a lower proton resistance (higher proton conductivity) of the CL in a previous report [12]. Generally, the ionomer loading in the CLs has a conflict between the proton conductivity and the porosity for reactant transport (e.g., gas, water) since overloaded ionomer in the CLs reduces the porosity while inadequate ionomer lowers the proton conductivity, respectively [7]. Shahgaldi et al. reported that the SSC ionomer is less sensitive to its loading with the ionomer ratios in the range between $17 \%$ and $30 \%$ due 
to the high uniformity coverage of $\mathrm{Pt}$ nanoparticles [28]. It was reported that $20 \mathrm{wt} \%$ of SSC Aquivion ${ }^{\circledR}$ D83-15C ionomer content in CLs exhibited the best performance under operating conditions at $95{ }^{\circ} \mathrm{C}$ and $\mathrm{RH}$ values of $30 \%, 50 \%$, and $70 \%$ [12]. Therefore, $20 \%$ of the SSC ionomer loading was selected in this work. In addition, the studies revealed that the optimal Nafion ${ }^{\circledR}$ loading in the CL was $\sim 30 \mathrm{wt} \%[29,30]$.

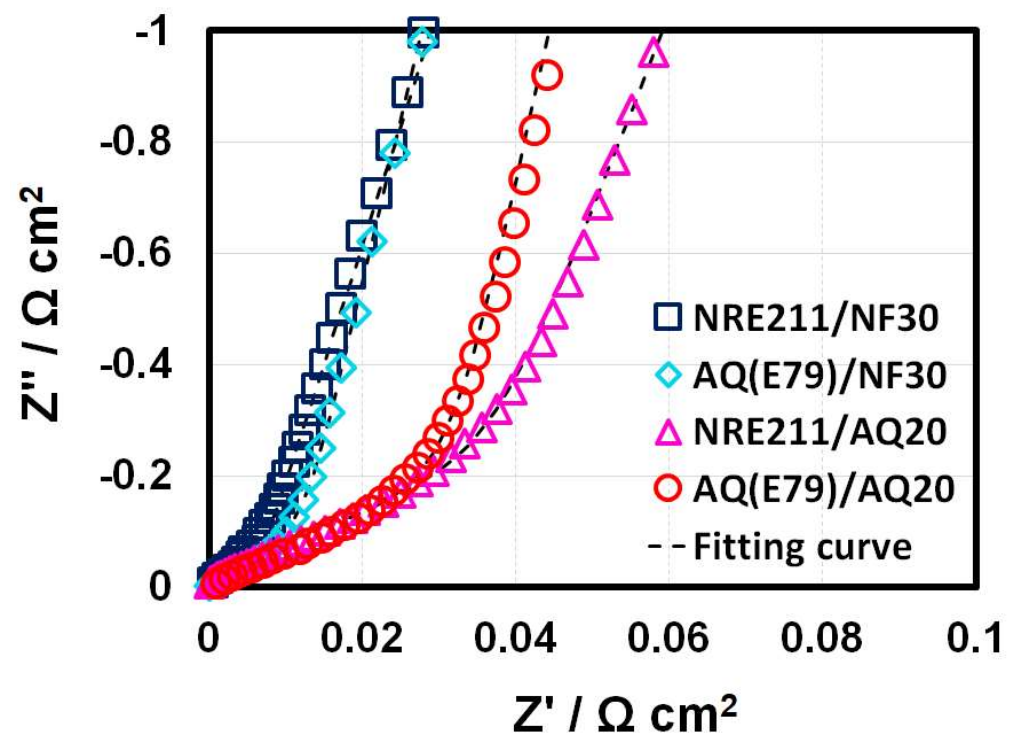

Figure 2. Nyquist plots of cathode CLs in the four MEAs under $80^{\circ} \mathrm{C}$ and $100 \% \mathrm{RH}$.

\subsection{ORR Kinetics}

$\mathrm{H}_{2} / \mathrm{O}_{2}$ polarization curves (PLs) of the four MEAs were recorded at $80{ }^{\circ} \mathrm{C}$ and $100 \%$ $\mathrm{RH}$ with excessive gas flow rates to elusive the losses associated with mass transport in the ORR kinetic range. Figure 3 shows the Tafel plots extracted from PLs using the $i R$-corrected electrode potentials (defined as the measured potential plus the $i R$ ) against the logarithm of the $\mathrm{H}_{2}$-crossover compensated current density (defined as the measured current density plus the $\left.\mathrm{iH}_{\mathrm{X}}\right)$. In the kinetic region $(\mathrm{E}>0.80 \mathrm{~V})$, the average Tafel slope for the MEAs with $30 \mathrm{wt} \%$ of Nafion ${ }^{\circledR}$ (NF30) $\left(\sim 68.5 \mathrm{mv} \mathrm{dec}^{-1}\right)$ were almost the same as the average Tafel slope of the MEAs with $20 \mathrm{wt} \%$ Aquivion ${ }^{\circledR}$ D83-15C (AQ20) (65.5 mv dec ${ }^{-1}$ ). This similarity implied that these four different MEAs demonstrated the similar inherent $\mathrm{Pt} / \mathrm{C}$ electrode kinetics towards ORR because the Pt catalyst coverage is uniform with sufficiently hydrated ionomer at $100 \% \mathrm{RH}$ [31]. The slightly higher Tafel slope of $\mathrm{AQ}(\mathrm{E} 79) / \mathrm{NF} 30\left(70 \mathrm{mVdec}^{-1}\right)$ probably can be attributed to the incompatibility of Nafion ${ }^{\circledR}$ ionomer with Aquivion ${ }^{\circledR}$ membrane [16].

The $\mathrm{H}_{2}$ /air polarization curves (PLs) collected at $80^{\circ} \mathrm{C}$ and various $\mathrm{RHs}$, as well as the membrane's ionic resistance $\left(\mathrm{R}_{\mathrm{Membr}}\right.$. predominate contribution to the cell ohmic resistance), are plotted in Figure 4. Three pieces of NRE211/NF30 were tested and used to establish the reproducibility of the MEA fabrication and testing procedures and their average PLs are shown in Figure 4. In the kinetic region (current densities $<0.1 \mathrm{~A} \mathrm{~cm}^{-2}$ ), the cell performances for all MEAs under various operation conditions were close (a difference in potential of $<10 \mathrm{mV}$ at $0.1 \mathrm{~A} \mathrm{~cm}^{-2}$ ), which is in agreement with the Tafel slope analysis shown in Figure 3. 


\section{Tafel Slope}

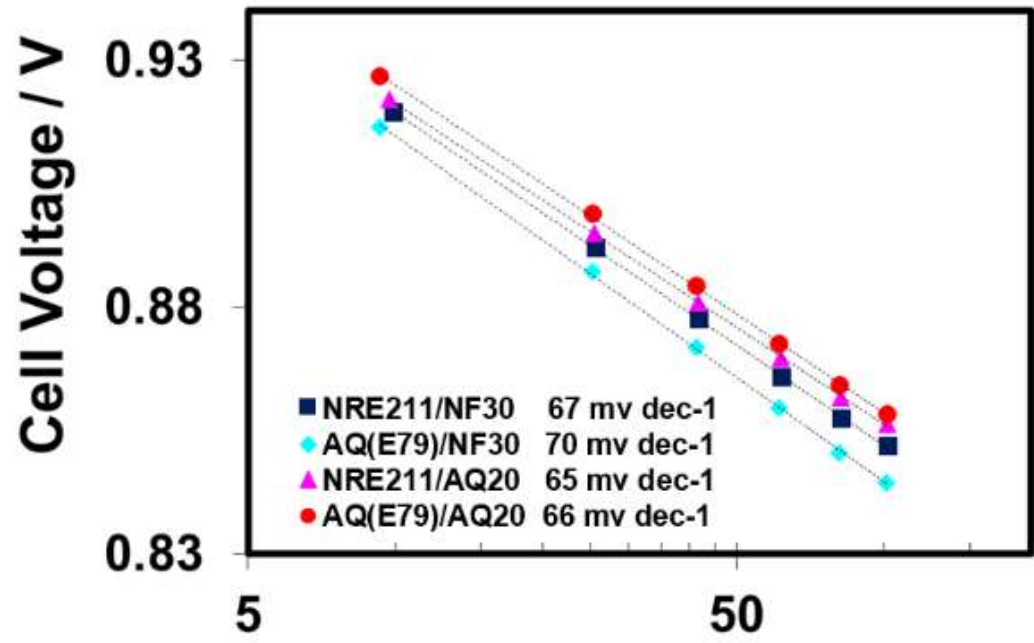

Current Density / $\mathrm{A} \mathrm{cm}^{-2}$

Figure 3. Tafel plots of $\mathrm{H}_{2} / \mathrm{O}_{2}$ polarization at $80{ }^{\circ} \mathrm{C}$ and $100 \% \mathrm{RH}$ for all investigated MEAs.

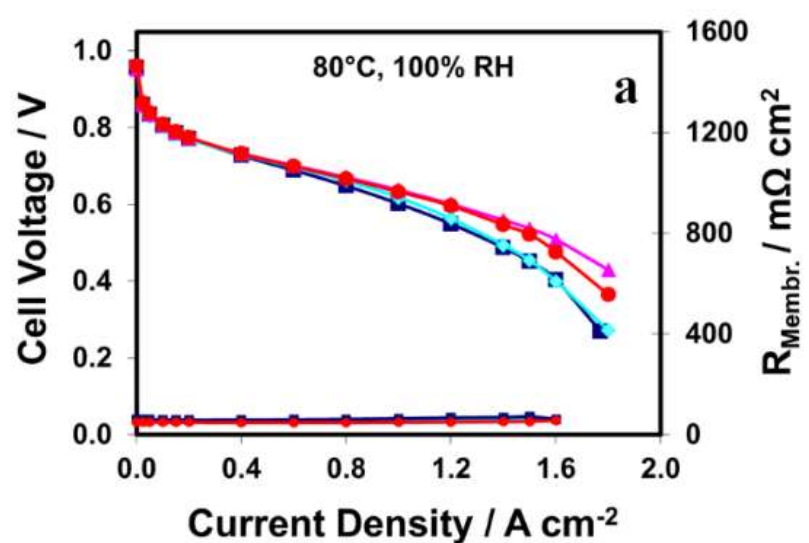

Current Density / $\mathrm{A} \mathrm{cm}^{-2}$

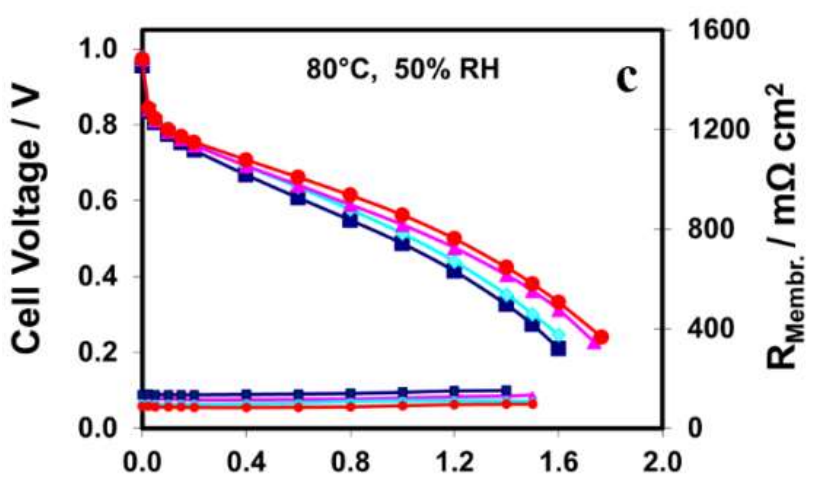

Current Density / $\mathrm{A} \mathrm{cm}^{-2}$
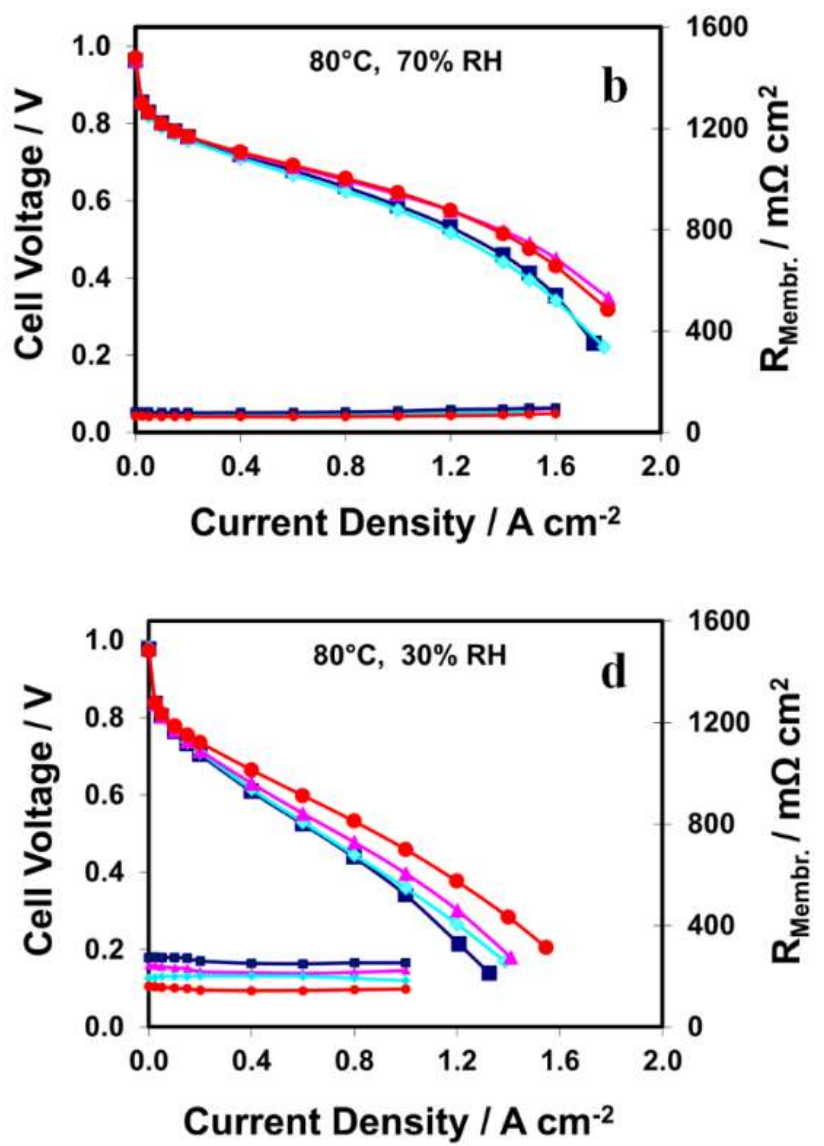

NRE211/AQ20

-NRE211/NF30 $A Q(E 79) / N F 30$

Figure 4. $\mathrm{H}_{2}$ / air polarization curves and membrane resistance $\left(\mathrm{R}_{\text {Membr. }}\right)$ at $80{ }^{\circ} \mathrm{C}$ and $\mathrm{RH}$ values of (a) $100 \%$; (b) $70 \%$; (c) $50 \%$; and (d) $30 \%$. 
In-situ EIS could provide some valuable insights into transport processes occurring in the MEAs. Figure 5 shows the in-situ EIS at $0.05 \mathrm{~A} \mathrm{~cm}^{-2}$ for the selected MEAs under various RH. At low current densities (e.g., $0.05 \mathrm{~A} \mathrm{~cm}^{-2}$ ), it is assumed that there are negligible losses associated with the transport of reactant gases to the electrode reactive sites since the oxygen consumption rate is small. For better comparison, the high-frequency intercepts are offset to zero. In Figure 5, each spectrum contains one small high-frequency (HF) capacitive arc and one big capacitive arc (1000-1 Hz). The small HF loop is almost negligible with respect to the big single semicircle (kinetic loop) [32]. Thus, only the kinetic loop was analyzed and fitted by a charge transfer resistance $\left(R_{c t}\right)$ in parallel with a constant phase element (CPE). The fitting curves (black solid lines) are shown in Figure 5.
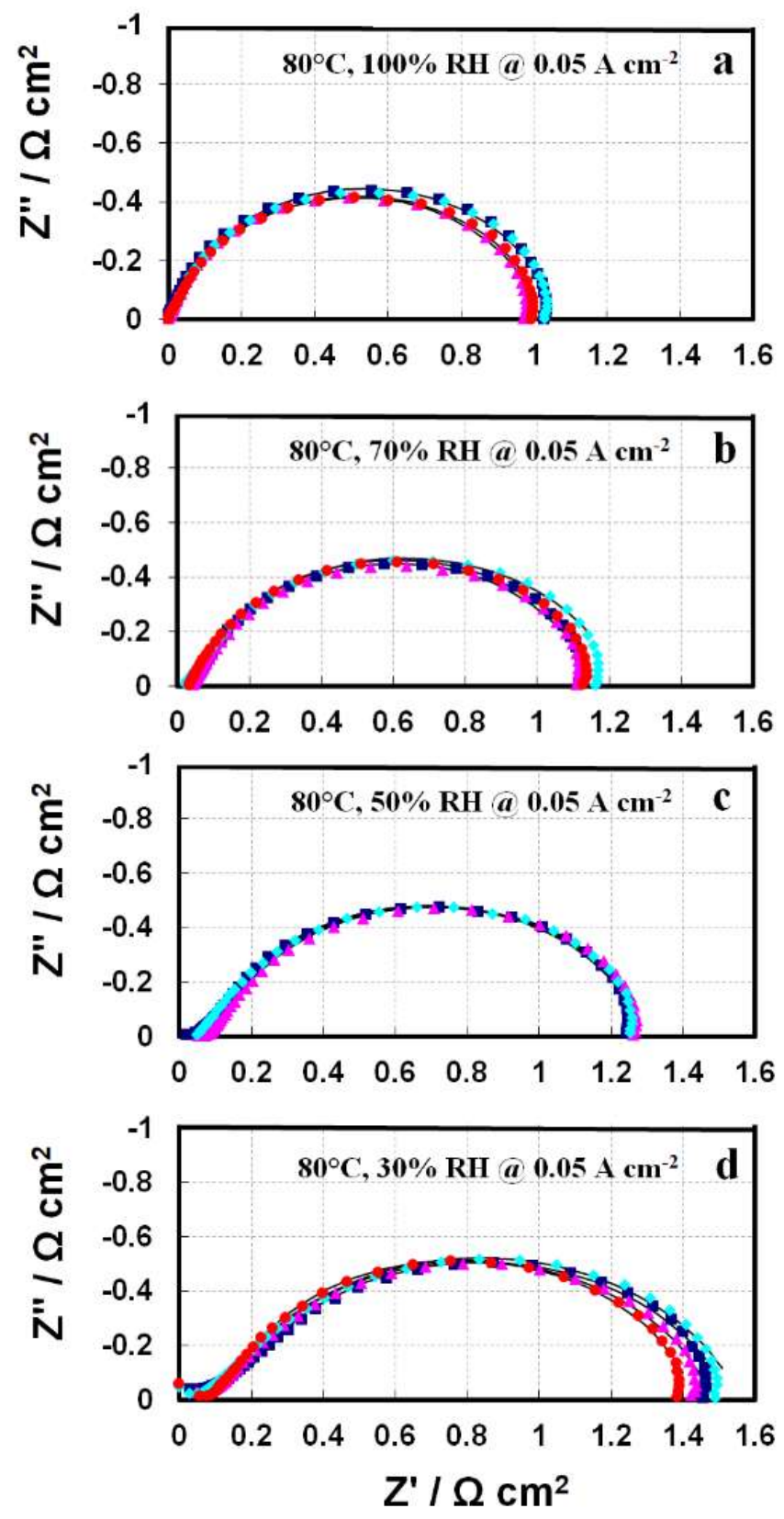

- NRE211/NF30 * AQ(E79)/NF30 $\triangle$ NRE211/AQ20 • AQ(E79)/AQ20

Figure 5. In-situ electrochemical impedance spectra obtained at $80^{\circ} \mathrm{C}, 0.05 \mathrm{~A} \mathrm{~cm}^{-2}$, and (a) $100 \%$; $\mathrm{RH}$ (b) $70 \% \mathrm{RH}$; (c) $50 \% \mathrm{RH}$; and (d) $30 \% \mathrm{RH}$. 
The difference in $R_{c t}$ for these four MEAs at each operation condition is slight, matching with the trend of PL curves in Figure 4. It implies that the similar ORR kinetics in these four samples can be associated with a comparable resistance, $\mathrm{R}_{\mathrm{ct}}$. Moreover, as the $\mathrm{RH}$ changes from $100 \%$ to $30 \%$, the $\mathrm{R}_{\mathrm{ct}}$ in Figure 5 for all the samples gradually increased from $1.04 \pm 0.02 \Omega \mathrm{cm}^{2}$ to $1.37 \pm 0.06 \Omega \mathrm{cm}^{2}$, along with the cell voltage drop from $806 \pm 3 \mathrm{mV}$ to $770 \pm 6 \mathrm{mV}$ in Figure 4, indicating that the reduced ORR kinetics (cell performance) at "dry" condition ( $\mathrm{RH} \mathrm{30 \% )} \mathrm{is} \mathrm{associated} \mathrm{to} \mathrm{the} \mathrm{larger} \mathrm{resistance,} \mathrm{R}_{\mathrm{ct}}$. With decreasing $\mathrm{RH}$, the $R_{c t}$ increases due to the dehydration of ionomer in both the membrane and catalyst layers, leading to proton conductivity losses and inferior catalyst-ionomer reactive interphase [16].

\subsection{Mass Transfer Losses}

By contrast, in the mass transport region (current densities $\geq 1.0 \mathrm{~A} \mathrm{~cm}^{-2}$ ) of the PL curves shown in Figure 4, the cell performances for the MEAs containing Aquivion ${ }^{\circledR}$ ionomer (AQ20) were consistently greater than that of MEAs containing Nafion ${ }^{\circledR}$ ionomer (NF30) and the voltage gap between them becomes even broader when either the current density increases from $1.0 \mathrm{~A} / \mathrm{cm}^{2}$ to $1.8 \mathrm{~A} / \mathrm{cm}^{2}$ or $\mathrm{RH}$ decreases from $100 \%$ to $30 \%$. For example, comparing between NRE211/NF30 and NRE211/AQ20 at $80{ }^{\circ} \mathrm{C}$ and 70\% RH, the difference in cell voltage increased from $\sim 30 \mathrm{mV}$ at $1.0 \mathrm{~A} \mathrm{~cm}^{-2}$ to $\sim 100 \mathrm{mV} 1.6 \mathrm{~A} \mathrm{~cm}^{-2}$. Furthermore, in comparison to NF30 based MEAs, the performance improvement of AQ20 based MEAs, was more pronounced at low RH.

Figure 6 a shows the cell voltage at a current density of $1.0 \mathrm{~A} \mathrm{~cm}^{-2}$ at $80{ }^{\circ} \mathrm{C}$ and various $\mathrm{RH}$. The maximum cell voltage differences between these four samples increased from $46 \mathrm{mV}$ to $118 \mathrm{mV}$ after $\mathrm{RH}$ was reduced from $70 \%$ to $30 \%$, indicating the advantage of SSC membrane/ionomer was more prominent under low $\mathrm{RH}$.
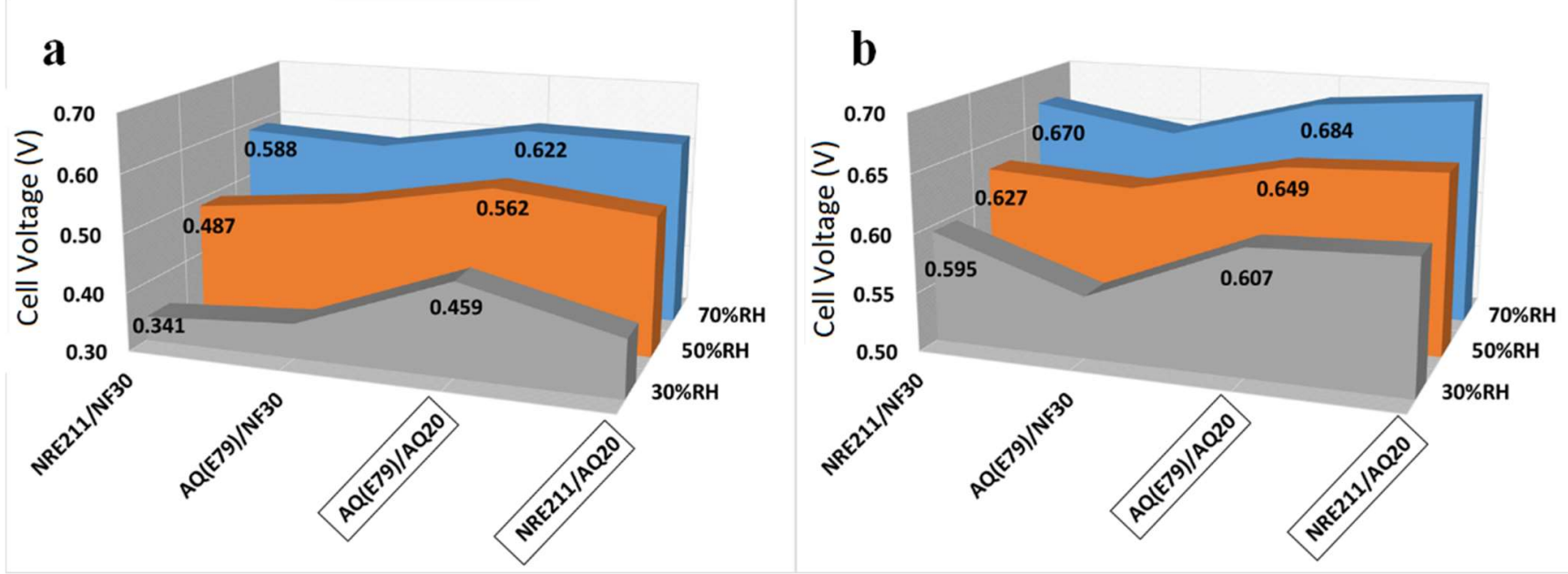

Figure 6. (a) Cell voltage without $i R$ correction; (b) cell voltage with $i R$ correction at a current density of $1.0 \mathrm{~A} \mathrm{~cm}^{-2}$ at $80{ }^{\circ} \mathrm{C}$ and various $\mathrm{RH}$.

In order to count out the effect of the membrane resistance $\left(\mathrm{R}_{\mathrm{Membr}}\right.$.) on the PLs, $i R$-compensated $\mathrm{H}_{2}$ /air polarization curves were calculated using $\mathrm{R}_{\mathrm{Membr}}$., as shown in Figure S2. The $i R$-compensated cell voltages at a current density of $1.0 \mathrm{~A} \mathrm{~cm}^{-2}$ are displayed in Figure $6 \mathrm{~b}$. After subtracting $\mathrm{R}_{\mathrm{Membr}}$, the MEAs containing $20 \%$ of SSC AQ ionomer (AQ20) exhibited higher cell performance than the MEAs containing 30\% of LSC Nafion ionomer (NF30), which is more pronounced under low RH (30\%) (Figure 6b). For example, the difference in cell voltage at $1.0 \mathrm{~A} \mathrm{~cm}^{-2}$ between AQ (E79)/NF30 and AQ (E79)/AQ20 increased from $35 \mathrm{mV}$ to $55 \mathrm{mV}$ when $\mathrm{RH}$ decreased from $70 \%$ to $30 \%$, revealing that the higher performance of AQ20 ionomer based MEAs over NF30 ionomer based MEAs can partially be attributed to the advantage of SSC ionomer in the catalyst layer. 
Moreover, when comparing the cell voltage with and without $i R$ correction at $1.0 \mathrm{~A} \mathrm{~cm}^{-2}$ shown in Figure 6, the contribution of SSC membrane to the superior cell performance is distinguishable, especially at low RH. For example, under conditions of $30 \% \mathrm{RH}$, the cell voltages with $i R$ correction for AQ(E79)/AQ20 and NRE211/AQ20 are almost identical while the cell voltage without $i R$ correction for AQ(E79)/AQ20 is over $60 \mathrm{mV}$ higher than that for NRE211/AQ20.

The same trend at high temperature $\left(95^{\circ} \mathrm{C}\right)$ was remarkably observed as above: increasingly higher relative performance for AQ20 based cells as RH was decreased (see Figure 7). This is more apparent when the $\mathrm{RH}$ was $<50 \%$. For example, under $30 \% \mathrm{RH}$ a potential of $433 \mathrm{mV}$ was generated for $\mathrm{AQ}(\mathrm{E} 79) / \mathrm{AQ} 20$ at $1.0 \mathrm{~A} \mathrm{~cm}^{-2}$ in comparison to $277 \mathrm{mV}$ for NRE211/NF30, representing a 56\% increment in power output. Of the four investigated MEAs under 30\% RH, AQ (E79)/AQ20 displayed the highest power density $\left(0.43 \mathrm{~W} \mathrm{~cm}^{-2}\right.$, see Figure $\left.7 \mathrm{~d}\right)$, followed by NRE211/AQ20 $\left(0.36 \mathrm{~W} \mathrm{~cm}^{-2}\right)$, and then AQ (E79)/NF30 (0.31 $\left.\mathrm{W} \mathrm{cm}^{-2}\right)$ and NRE211/NF30 $\left(0.30 \mathrm{~W} \mathrm{~cm}^{-2}\right)$.
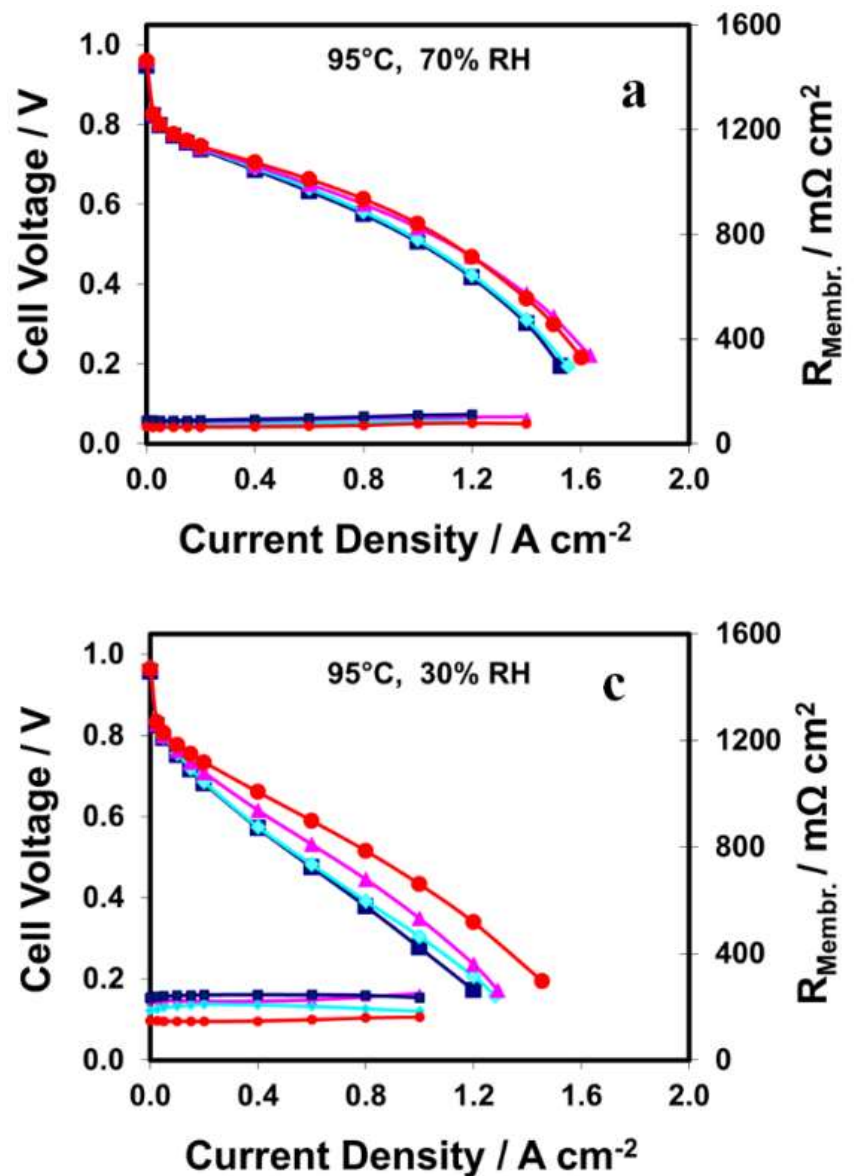

- -NRE211/NF30

\section{$A Q(E 79) / N F 30$}

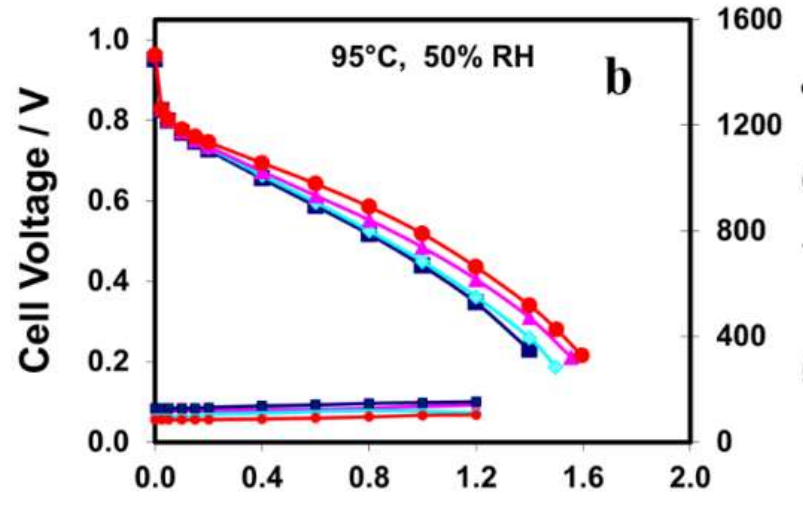

Current Density / $\mathrm{A} \mathrm{cm}^{-2}$

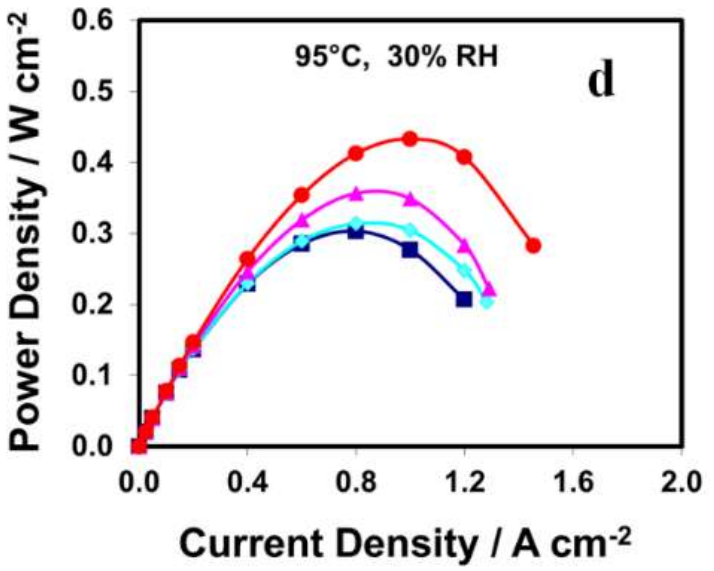

NRE211/AQ20

\section{$A Q(E 79) / A Q 20$}

Figure 7. $\mathrm{H}_{2}$ / air polarization curves and membrane resistance $\left(\mathrm{R}_{\mathrm{Membr}}\right.$. $)$ at $95^{\circ} \mathrm{C}$ and $\mathrm{RH}$ values of (a) $70 \%$, (b) $50 \%$, (c) $30 \%$, as well as power densitites at $\mathrm{RH}$ of (d) $30 \%$.

\subsection{Cell Resistance}

In order to further understand the observed behaviors of these four MEAs at various operating conditions, in-situ EIS were obtained for the MEAs at $1.0 \mathrm{~A} \mathrm{~cm}^{-2}$ shown in Figure 8. The Nyquist plots of the tested MEAs contains one high-frequency (HF) capacitive loop, one medium-frequency (MF) capacitive loop, and one low-frequency (LF) capacitive loop. For comparison, the high-frequency intercepts are offset to zero. The charge transfer resistance $\left(R_{c t}\right)$, membrane resistance $\left(R_{m}\right)$, and mass transfer resistance $\left(R_{m t}\right)$ were 
fitted using the equivalent circuit [33] shown in Figure 8, and the experimental section in supporting materials. The fitting curves (solid line) and fitting results are presented in Figures 8 and 9 , respectively.
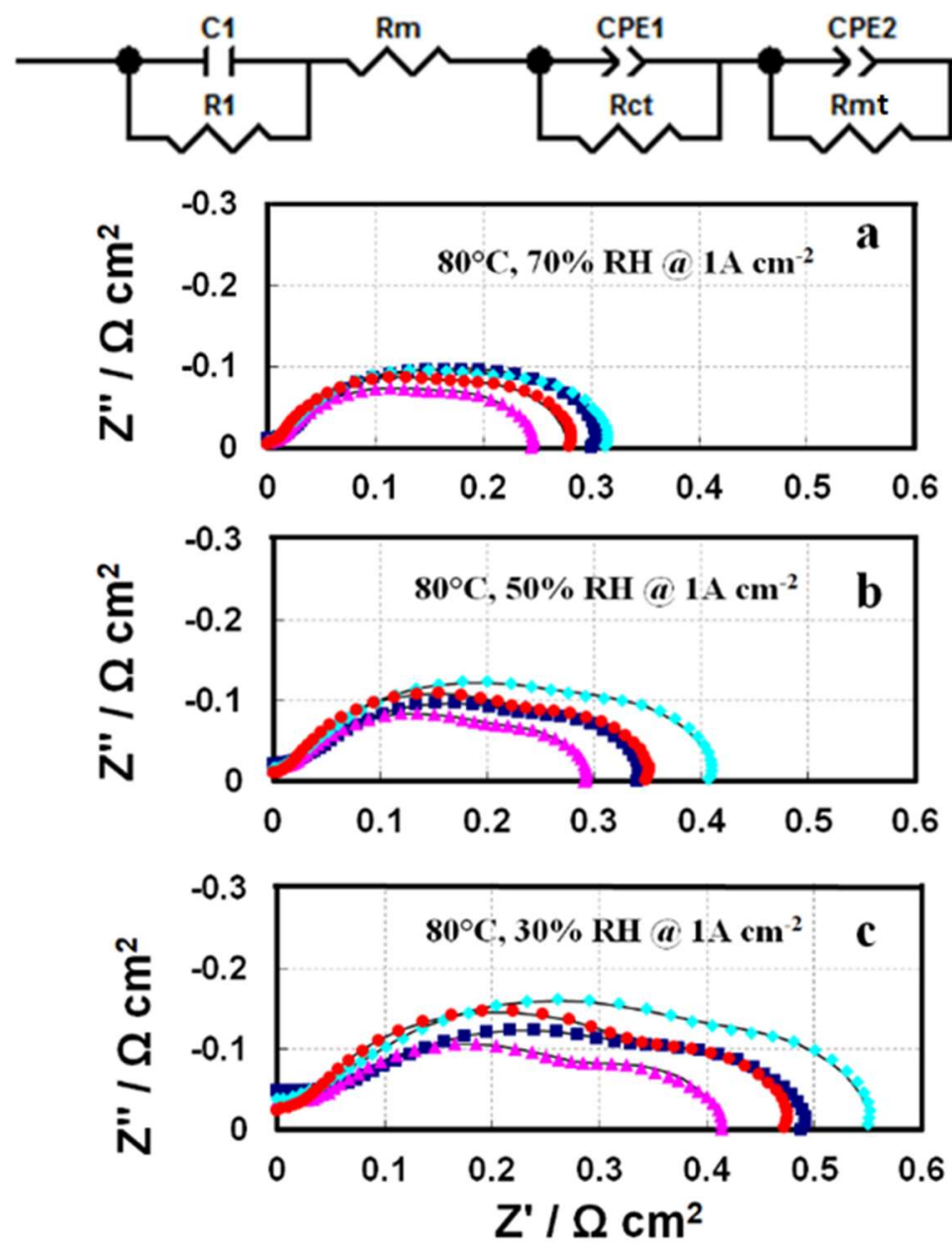

\section{NRE211/NF30 $\bullet A Q(E 79) / N F 30 \triangle N R E 211 / A Q 20 \bullet A Q(E 79) / A Q 20$}

Figure 8. In-situ electrochemical impedance spectra of four investigated MEAs at a current density of $1.0 \mathrm{~A} \mathrm{~cm}^{2}$ at $80{ }^{\circ} \mathrm{C}$ under $\mathrm{RH}$ of (a) $70 \%$; (b) $50 \%$; and (c) $30 \%$.

\subsubsection{Membrane Resistance}

Membrane resistance primarily contributes to the cell ohmic resistance. The trend for $R_{m}$ from EIS fitting in Figure 9a is well-matched to the membrane resistance $\left(R_{m e m b r}\right.$. collected by the current interrupt technique in Figure 4: SSC AQ(E79) membrane-based cells yielded lower membrane resistances $\left(R_{\text {membr }} / R_{m}\right)$ and higher conductivities compared to LSC NRE-211membrane-based cells under all fuel cell operating conditions. Among the four samples, $A Q(E 79) / A Q 20$ exhibits a minimum membrane resistance $\left(R_{\text {membr. }} / R_{m}\right)$ and a corresponding maximum conductivity (See Table 3 ). This trend is more significant when $\mathrm{RH}$ is reduced, which is linked to the inherent properties of the SSC polymer such as high IEC, high crystallinity and high water content. 

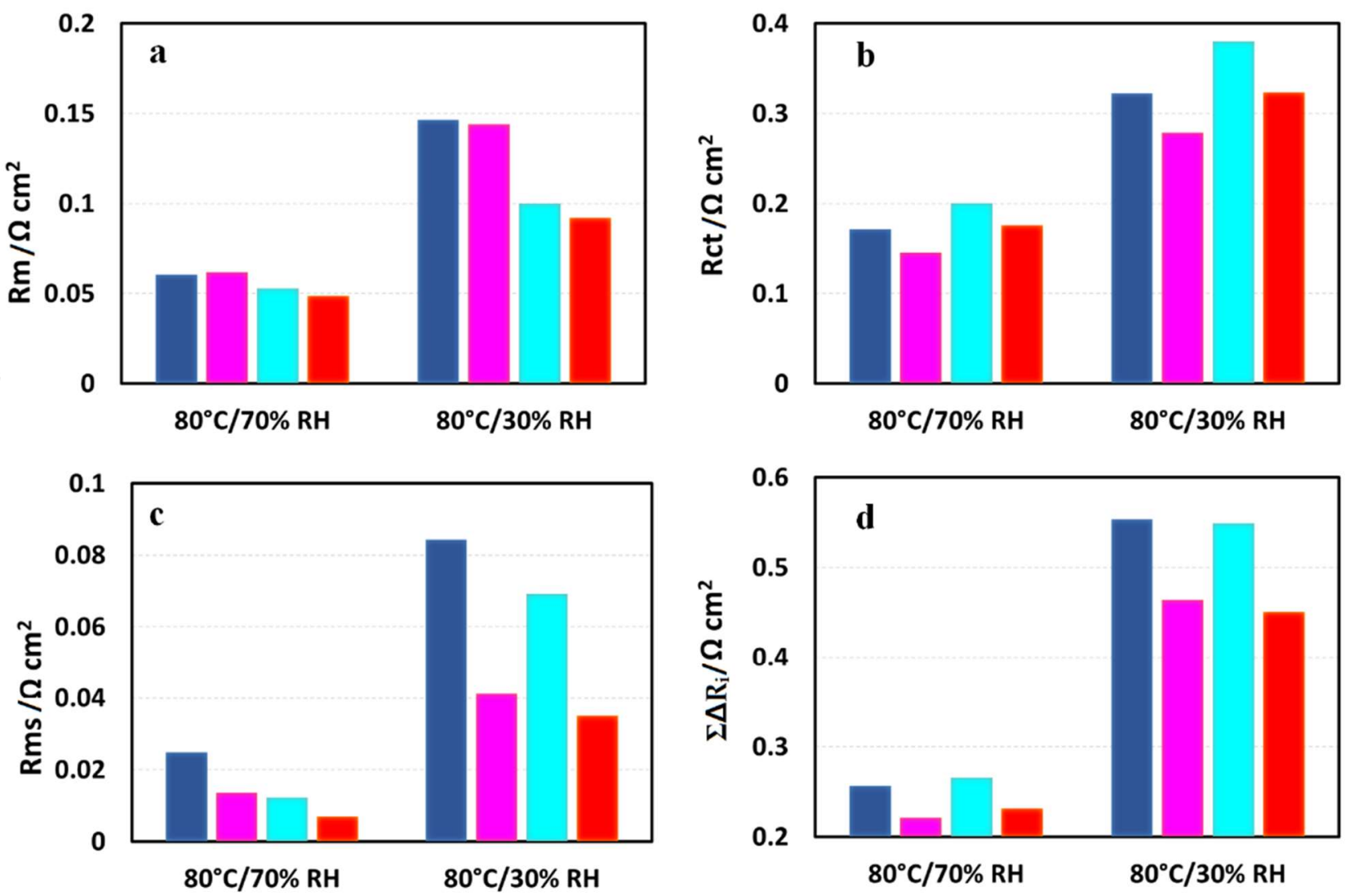

NRE211/NF30 $\square$ NRE211/AQ20 $\square$ AQ(E79)/NF30 $\backsim A Q(E 79) / A Q 20$

Figure 9. (a) Membrane resistance $\left(\mathrm{R}_{\mathrm{m}}\right)$; (b) charge transfer resistance $\left(\mathrm{R}_{\mathrm{ct}}\right)$; $(\mathrm{c})$ mass transfer resistance $\left(\mathrm{R}_{\mathrm{mt}}\right)$; and $(\mathrm{d})$ overall resistances $\left(\Sigma \Delta \mathrm{R}_{\mathrm{i}}\right)$ of each MEA calculated from EIS data at $80{ }^{\circ} \mathrm{C}$ under $70 \%$ and $30 \%$ of RH.

Table 3. Membrane resistances and relative conductivities calculated from both $\mathrm{R}_{\mathrm{Membr}}$. and in-situ EIS at $1.0 \mathrm{~A} \mathrm{~cm}^{-2}$ at $80{ }^{\circ} \mathrm{C}$ under $70 \% \mathrm{RH}$ vs. $30 \% \mathrm{RH}$.

\begin{tabular}{|c|c|c|c|c|}
\hline MEAs & NRE-211/NF30 & NRE-211/AQ20 & AQ (E79)/NF30 & AQ (E79)/AQ20 \\
\hline \multicolumn{5}{|c|}{$80^{\circ} \mathrm{C}, 70 \% \mathrm{RH}$} \\
\hline $\mathrm{R}_{\mathrm{Membr}} \cdot(\mathrm{m} \Omega)$ & $3.27 \pm 0.03$ & $3.15 \pm 0.05$ & $3.47 \pm 0.02$ & $2.94 \pm 0.02$ \\
\hline $\begin{array}{c}\sigma_{\mathrm{R}} \\
\left(\mathrm{mS} \mathrm{cm}^{-1}\right)\end{array}$ & $34.25 \pm 0.31$ & $35.56 \pm 0.56$ & $38.04 \pm 0.22$ & $44.90 \pm 0.31$ \\
\hline $\mathrm{R}_{\mathrm{m}}(\mathrm{m} \Omega)$ & 2.42 & 2.48 & 2.11 & 1.95 \\
\hline $\begin{array}{c}\sigma_{\mathrm{Rm}} \\
\left(\mathrm{mS} \mathrm{cm}^{-1}\right)\end{array}$ & 46.28 & 45.16 & 62.56 & 67.69 \\
\hline \multicolumn{5}{|c|}{$80^{\circ} \mathrm{C}, 30 \% \mathrm{RH}$} \\
\hline $\mathrm{R}_{\mathrm{Membr}} \cdot(\mathrm{m} \Omega)$ & $10.14 \pm 0.07$ & $8.62 \pm 0.03$ & $7.73 \pm 0.02$ & $5.90 \pm 0.02$ \\
\hline $\begin{array}{c}\sigma_{\mathrm{R}} \\
\left(\mathrm{mS} \mathrm{cm}^{-1}\right)\end{array}$ & $11.05 \pm 0.07$ & $12.99 \pm 0.05$ & $17.08 \pm 0.05$ & $22.37 \pm 0.07$ \\
\hline $\mathrm{R}_{\mathrm{m}}(\mathrm{m} \Omega)$ & 5.86 & 5.76 & 4.00 & 3.68 \\
\hline $\begin{array}{c}\sigma_{\mathrm{Rm}} \\
\left(\mathrm{mS} \mathrm{cm}^{-1}\right)\end{array}$ & 19.11 & 19.44 & 33.00 & 35.87 \\
\hline
\end{tabular}




\subsubsection{Charge Transfer Resistance}

The effective charge transfer resistance $\left(R_{c t}\right)$ represents in the medium frequency domain in EIS associated with the ORR kinetics of the CL. AQ20 ionomer in CLs presents lower $\mathrm{R}_{\mathrm{ct}}$ than NF30 ionomer under both $70 \% \mathrm{RH}$ and $30 \% \mathrm{RH}$ that led to the superior performance of the SSC AQ ionomer in CLs over that of the LSC Nafion ionomer. The improvement in the cell performance for the MEAs with SSC ionomer in CLs could be on account of better ionomer coverage in the CLs, superior proton conductivity, less equivalent weight, and greater porosity [7]. It is worth mentioning that AQ(E79)/AQ20 shows the best performance amongst the four samples, while the $R_{c t}$ of this sample is still slightly higher than NRE211/AQ20, indicating that the outstanding performance of $\mathrm{AQ}(\mathrm{E79}) / \mathrm{AQ} 20$ benefits from the advantages of better compatibility of SSC membranes and SSC ionomer in CLs. We hypothesized that the marginally greater $R_{c t}$ for AQ(E79)/AQ20 than NRE211/AQ20 $\left(0.323 \Omega \mathrm{cm}^{2}\right.$ vs. $0.279 \Omega \mathrm{cm}^{2}$ under $\left.30 \% \mathrm{RH}\right)$ is due to some possible deleterious effects from the combination of the high water content of the Aquivion ${ }^{\circledR}$ membrane and ionomer: (i) dilution of the local proton concentration associated with swollen membrane and ionomer, (ii) decline of the oxygen solubility in the ionomer because of the high hydrophilicity of SSC ionomer, and (iii) relative high interfacial resistance between membrane and CL due to considerable SSC membrane dimensional change under fuel cell operation conditions.

\subsubsection{Mass Transfer Resistance}

Mass transfer resistance $\left(\mathrm{R}_{\mathrm{mt}}\right)$ displays in the low frequency domain in EIS that mainly responses for the mass transfer resistance of the gas phase within the backing and the CL. The $R_{m t}$ trend for the different MEA combinations is AQ(E79)/AQ20 < AQ(E79)/NF30 < NRE211/AQ20 < NRE211/NF30 under relative high humidity (70\% RH) while AQ(E79)/AQ20 < NRE211/AQ20 < AQ(E79)/NF30 < NRE211/NF30 under dry condition (30\% RH). It suggested that AQ(E79)/AQ20 has less mass transport problems, due to greater water management. The configuration of SSC membrane and SSC ionomer in CL has adequate water retention capability to prevent flooding issues under fully humidified conditions as well as effective water trapping in both membrane and CLs (excellent water uptake) to avoid MEA dehydration under dry conditions. As a result, either SSC membrane or SSC ionomer in CLs could reduce mass transport diffusion compared to its alternative LSC Nafion [34,35].

\subsubsection{Overall Resistance and Individual Contribution}

The overall cell resistance is the sum of the membrane resistance $\left(R_{m}\right)$, the charge resistance $\left(R_{c t}\right)$, and the mass transfer $\left(R_{m t}\right)$. The $R_{m}$ is mainly contributed to the cell ohmic resistance, the $R_{c t}$ represents the charge transfer resistance (kinetic resistance) and the $R_{m t}$ is more related to gas transport and water management. The individual resistance $\left(\Delta R_{i}\right)$ as well as the overall resistances $\left(\Sigma \Delta R_{i}\right)$ of each MEA show a clear increase as $\mathrm{RH}$ decreased from $70 \%$ to $30 \%$. The overall resistance ranking at $80{ }^{\circ} \mathrm{C}$ is $\mathrm{AQ}(\mathrm{E} 79) / \mathrm{AQ} 20 \approx \mathrm{NRE} 211 / \mathrm{AQ} 20<\mathrm{AQ}(\mathrm{E} 79) / \mathrm{NF} 30 \approx \mathrm{NRE} 211 / \mathrm{NF30}$ under wet condition $(100 \%$, 70\%, and 50\% RH, while AQ(E79)/AQ20 < NRE211/AQ20 < NRE211/NF30 $\approx \mathrm{AQ}(\mathrm{E} 79) / \mathrm{NF30}$ under dry condition (30\% RH), which could explain the performance difference of PLs in Figure 4.

Studying the relative contribution of each resistance to the overall resistance increase could further elucidate the performance differences between these MEAs and provide some valuable insights for MEA design. Each component of this breakdown can be defined as $\Delta R_{i} / \Sigma \Delta R_{i}$, in which $R_{i}$ represents $R_{m}, R_{c t}$, or $R_{m t}$. In Figure 10 , the contribution of individual resistance is graphed under $70 \%$ and $30 \% \mathrm{RH}$, showing that $\mathrm{R}_{\mathrm{ct}}$ comprises the majority of the total resistance and then followed by $R_{m}$ and the least $R_{m t}$. It suggests that the utilization of SSC ionomer as an alternative ionomer in CLs could bring more benefit than the substitution of LSC membrane with SSC membrane for the better cell performance. Moreover, when $\mathrm{RH}$ was reduced to $30 \%$, the contribution of $\mathrm{R}_{m}$ for AQ (E79) based MEA 
went down, however for NRE211 based MEA, the portion of $R_{m}$ in the total resistance increased by $\sim 4 \%$, indicating NRE211 experiences some dehydration under dry condition comparing to SSC membrane.
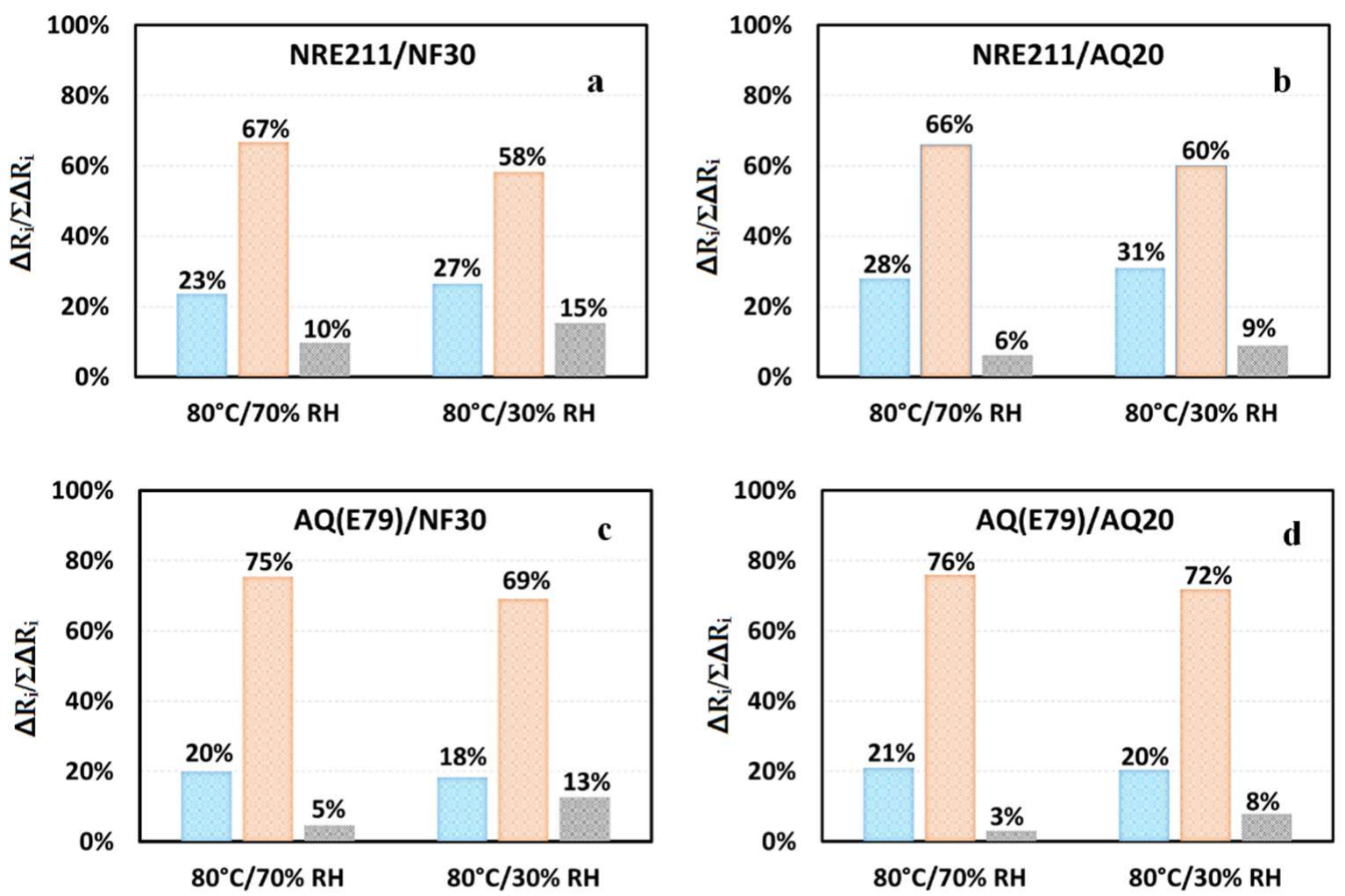

Membrane Kinetic Mass Transfer

Figure 10. Relative contribution of each resistance to the overall resistance $(\Delta \mathrm{Ri} / \Sigma \Delta \mathrm{Ri})$ for the selected MEAs (a) NRE-211/NF30, (b) NRE211/AQ20, (c) AQ(E79)/NF30, and (d) AQ(E79)/AQ20 at $80{ }^{\circ} \mathrm{C}$ under $70 \%$ and $30 \%$ of $\mathrm{RH}$.

\section{Conclusions}

The fuel cell performance was evaluated and compared between the four MEAs with the combinations of SSC PFSA and LSC PFSA polymers as ionomers in CL and as membrane materials in MEAs, named as NRE211/NF30, NRE211/AQ20, AQ(E79)/NF30, and $A Q(E 79) / A Q 20$. According to the results of various electrochemical diagnoses such as ECSA, protonic resistance in CLs, $\mathrm{H}_{2}$ crossover, PLs, cell resistance through in-situ EIS measured at different $\mathrm{RH} \%$ at $80^{\circ} \mathrm{C}$ and $95^{\circ} \mathrm{C}$, it was found that SSC PFSA polymer used as membrane and ionomer in CL yields better fuel cell performance than LSC PFSA polymer, especially at high temperature and low RH conditions. Among the four investigated MEAs, $\mathrm{AQ}(\mathrm{E} 79) / \mathrm{AQ} 20$ demonstrated the best cell performance at $80^{\circ} \mathrm{C}$ and $95^{\circ} \mathrm{C}$ especially under $30 \%$ of $\mathrm{RH}$ benefiting from the concurrence of both SSC membranes and SSC ionomer in CLs and the better compatibility effects using the same polymer material. The less mass transfer resistance of this MEA in EIS indicates a better water management with SSC polymer, which could avoid dehydration in either the membrane or catalyst layer under "dry" conditions (e.g., 30\% RH) as well as mitigate catalyst layer flooding under "wet" conditions (e.g., 100\% RH). Moreover, it suggests that SSC polymer as an ionomer in CLs could result in a more noticeable improvement in cell performance than SSC polymer as a membrane material in MEA, since the charge transfer resistance in the kinetic range contributed more to the overall cell resistance than the membrane resistance did. 
Supplementary Materials: The following are available online at https: / / www.mdpi.com/article/ 10.3390/ma15010078/s1, Figure S1: Schematic diagram of membrane-electrode assembly (MEA). Figure S2: $i R$-compensated PLs for all the MEAs at $80{ }^{\circ} \mathrm{C}$ and various RH. Method: In-situ EIS.

Author Contributions: Conceptualization, N.Z. and Z.S.; methodology, N.Z.; writing-original draft preparation, N.Z.; writing-review and editing, Z.S. and F.G.; supervision, Z.S.; project administration, Z.S.; funding acquisition, Z.S. All authors have read and agreed to the published version of the manuscript.

Funding: This research received no external funding.

Institutional Review Board Statement: Not applicable.

Informed Consent Statement: Not applicable.

Data Availability Statement: Not applicable.

Acknowledgments: The authors would like to thank Ken Tsay for the helps in experimental setting up, and thank Chao Lei and Zhong Xie for technical discussion.

Conflicts of Interest: The authors declare no conflict of interest.

\section{References}

1. Wu, H.-W. A review of recent development: Transport and performance modeling of PEM fuel cells. Appl. Energy 2016, 165, 81-106. [CrossRef]

2. Wang, J. System integration, durability and reliability of fuel cells: Challenges and solutions. Appl. Energy 2017, 189, 460-479. [CrossRef]

3. Thompson, S.T.; James, B.D.; Huya-Kouadio, J.M.; Houchins, C.; De Santis, D.A.; Ahluwalia, R.; Wilson, A.R.; Kleen, G.; Papageorgopoulos, D. Direct hydrogen fuel cell electric vehicle cost analysis: System and high-volume manufacturing description, validation, and outlook. J. Power Sources 2018, 399, 304-313. [CrossRef]

4. Whiston, M.M.; Azevedo, I.L.; Litster, S.; Whitefoot, K.S.; Samaras, C.; Whitacre, J.F. Expert assessments of the cost and expected future performance of proton exchange membrane fuel cells for vehicles. Proc. Natl. Acad. Sci. USA 2019, 116, 4899. [CrossRef] [PubMed]

5. $\quad$ Church, S. Del. Firm Installs Fuel Cell. The News Journal, 6 January 2006; B7.

6. Kundu, P.P.; Pal, A. Cation exchange polymeric membranes for fuel cells. Rev. Chem. Eng. 2006, 22, 125-153. [CrossRef]

7. Shahgaldi, S.; Alaefour, I.; Li, X. The impact of short side chain ionomer on polymer electrolyte membrane fuel cell performance and durability. Appl. Energy 2018, 217, 295-302. [CrossRef]

8. Boakye, E.E.; Yeager, H.L. Water sorption and ionic diffusion in short side chain perfluorosulfonate ionomer membranes. J. Membr. Sci. 1992, 69, 155-167. [CrossRef]

9. Eisman, G.A. The application of Dow Chemical's perfluorinated membranes in proton-exchange membrane fuel cells. J. Power Sources 1990, 29, 389-398. [CrossRef]

10. Prater, K. The renaissance of the solid polymer fuel cell. J. Power Sources 1990, 29, 239-250. [CrossRef]

11. Gebert, M.; Ghielmi, A.; Merlo, L.; Corasaniti, M.; Arcella, V. AQUIVIONTM_The short-side-chain and low-EW PFSA for next-generation PEFCs expands production and utilization. ECS Trans. 2010, 26, 279-283. [CrossRef]

12. Peron, J.; Edwards, D.; Haldane, M.; Luo, X.; Zhang, Y.; Holdcroft, S.; Shi, Z. Fuel cell catalyst layers containing short-side-chain perfluorosulfonic acid ionomers. J. Power Sources 2011, 196, 179-181. [CrossRef]

13. Lei, C.; Bessarabov, D.; Ye, S.; Xie, Z.; Holdcroft, S.; Navessin, T. Low equivalent weight short-side-chain perfluorosulfonic acid ionomers in fuel cell cathode catalyst layers. J. Power Sources 2011, 196, 6168-6176. [CrossRef]

14. Zhao, N.; Edwards, D.; Lei, C.; Wang, K.; Li, J.; Zhang, Y.; Holdcroft, S.; Shi, Z. The importance of water transport on short-side chain perfluorosulfonic acid membrane fuel cells operating under low relative humidity. J. Power Sources 2013, 242, 877-883. [CrossRef]

15. Stassi, A.; Gatto, I.; Passalacqua, E.; Antonucci, V.; Arico, A.S.; Merlo, L.; Oldani, C.; Pagano, E. Performance comparison of long and short-side chain perfluorosulfonic membranes for high temperature polymer electrolyte membrane fuel cell operation. $J$. Power Sources 2011, 196, 8925-8930. [CrossRef]

16. Wu, X.; Scott, K.; Puthiyapura, V. Polymer electrolyte membrane water electrolyser with Aquivion ${ }^{\circledR}$ short side chain perfluorosulfonic acid ionomer binder in catalyst layers. Int. J. Hydrogen 2012, 37, 13243-13248. [CrossRef]

17. Talukdar, K.; Gazdzicki, P.; Friedrich, K.A. Comparative investigation into the performance and durability of long and short side chain ionomers in Polymer Electrolyte Membrane Fuel Cells. J. Power Sources 2019, 439, 227078. [CrossRef]

18. Cha, D.; Jeon, S.W.; Yang, W.; Kim, D.; Kim, Y. Comparative performance evaluation of self-humidifying PEMFCs with short-sidechain and long-side-chain membranes under various operating conditions. Energy 2018, 150, 320-328. [CrossRef] 
19. Balogun, E.O.; Hussain, N.; Chamier, J.; Barendse, P. Performance and durability studies of perfluorosulfonic acid ionomers as binders in PEMFC catalyst layers using Electrochemical Impedance Spectroscopy. Int. J. Hydrogen Energy 2019, 44, 32219-32230. [CrossRef]

20. Li, T.; Shen, J.; Chen, G.; Guo, S.; Xie, G. Performance Comparison of Proton Exchange Membrane Fuel Cells with Nafion and Aquivion Perfluorosulfonic Acids with Different Equivalent Weights as the Electrode Binders. ACS Omega 2020, 5, 17628-17636. [CrossRef]

21. Ren, H.; Teng, Y.; Meng, X.; Fang, D.; Huang, H.; Geng, J.; Shao, Z. Ionomer network of catalyst layers for proton exchange membrane fuel cell. J. Power Sources 2021, 506, 230186. [CrossRef]

22. Primachenko, O.N.; Marinenko, E.A.; Odinokov, A.S.; Kononova, S.V.; Kulvelis, Y.V.; Lebedev, V.T. State of the art and prospects in the development of proton-conducting perfluorinated membranes with short side chains: A review. Polym. Adv. Technol. 2021, 32, 1386-1408. [CrossRef]

23. Xie, Z.; Zhao, X.; Adachi, M.; Shi, Z.; Mashio, T.; Ohma, A.; Shinohara, K.; Holdcroft, S.; Navessin, T. Fuel cell cathode catalyst layers from "green" catalyst inks. Energy Environ. Sci. 2008, 1, 184-193. [CrossRef]

24. Mohamed, H.F.M.; Ito, K.; Kobayashi, Y.; Takimoto, N.; Takeoka, Y.; Ohira, A. Free volume and permeabilities of O2 and H2 in Nafion membranes for polymer electrolyte fuel cells. Polymer 2008, 49, 3091-3097. [CrossRef]

25. Sodaye, H.S.; Pujari, P.K.; Goswami, A.; Manohar, S.B. Probing the microstructure of Nafion-117 using positron annihilation spectroscopy. J. Polym. Sci. B Polym. Phys. 1997, 35, 771-776. [CrossRef]

26. Ghielmi, A.; Vaccarono, P.; Troglia, C.; Arcella, V. Proton exchange membranes based on the short-side-chain perfluorinated ionomer. J. Power Sources 2005, 145, 108-115. [CrossRef]

27. Zhang, H.; Li, J.; Tang, H.; Lin, Y.; Pan, M. Hydrogen crossover through perfluorosulfonic acid membranes with variable side chains and its influence in fuel cell lifetime. Int. J. Hydrogen 2014, 39, 15989-15995. [CrossRef]

28. You, D.J.; Kwon, K.; Joo, S.H.; Kim, J.H.; Kim, J.M.; Pak, C.; Chang, H. Carbon-supported ultra-high loading Pt nanoparticle catalyst by controlled overgrowth of Pt: Improvement of Pt utilization leads to enhanced direct methanol fuel cell performance. Int. J. Hydrogen 2012, 37, 6880-6885. [CrossRef]

29. Passalacqua, E.; Lufrano, F.; Squadrito, G.; Patti, A.; Giorgi, L. Nafion content in the catalyst layer of polymer electrolyte fuel cells: Effects on structure and performance. Electrochim. Acta 2001, 46, 799-805. [CrossRef]

30. Kim, K.-H.; Lee, K.-Y.; Kim, H.-J.; Cho, E.; Lee, S.-Y.; Lim, T.-H.; Yoon, S.P.; Hwang, I.C.; Jang, J.H. The effects of Nafion ${ }^{\circledR}$ ionomer content in PEMFC MEAs prepared by a catalyst-coated membrane (CCM) spraying method. Int. J. Hydrogen 2010, 35, $2119-2126$. [CrossRef]

31. Neyerlin, K.C.; Gasteiger, H.A.; Mittelsteadt, C.K.; Jorne, J.; Gu, W. Effect of Relative Humidity on Oxygen Reduction Kinetics in a PEMFC. J. Electrochem. Soc. 2005, 152, A1073. [CrossRef]

32. Zhiani, M.; Majidi, S.; Taghiabadi, M.M. Comparative Study of On-Line Membrane Electrode Assembly Activation Procedures in Proton Exchange Membrane Fuel Cell. Fuel Cells 2013, 13, 946-955. [CrossRef]

33. Zhao, N.; Yuan, X.-Z.; Girard, F.; Wang, K.; Li, J.; Shi, Z.; Xie, Z. Effects of Membrane Additives on PEMFC Conditioning. Chem. Sel. 2019, 4, 12649-12655. [CrossRef]

34. Park, Y.-C.; Kakinuma, K.; Uchida, H.; Watanabe, M.; Uchida, M. Effects of short-side-chain perfluorosulfonic acid ionomers as binders on the performance of low Pt loading fuel cell cathodes. J. Power Sources 2015, 275, 384-391. [CrossRef]

35. Park, Y.C.; Tokiwa, H.; Kakinuma, K.; Watanabe, M.; Uchida, M. Effects of carbon supports on Pt distribution, ionomer coverage and cathode performance for polymer electrolyte fuel cells. J. Power Sources 2016, 315, 179-191. [CrossRef] 